\title{
Evaluation of Entomopathogenic Bacteria Against Pseudaulacaspis pentagona (Targioni-Tozzetti) (Hemiptera: Diaspididae)* $^{*}$
}

\author{
Elif Tozlu, Recep Kotan \\ Atatürk University, Faculty of Agriculture, Department of Plant Protection, \\ Erzurum, Turkey \\ Göksel Tozlu (Corresponding author) \\ Atatürk University, Faculty of Agriculture, Department of Plant Protection, \\ Erzurum, Turkey \\ E-mail: gtozlu@atauni.edu.tr
}

\begin{abstract}
Nasibe Tekiner, Önder Çalmaşur, Fatih Dadaşoğlu
Atatürk University, Faculty of Agriculture, Department of Plant Protection, Erzurum, Turkey
\end{abstract}

Received: Aug. 13, 2020

doi:10.5296/jas.v8i4.17519
Accepted: Sep. 15, $2020 \quad$ Published: Sep. 23, 2020

URL: https://doi.org/10.5296/jas.v8i4.17519

\begin{abstract}
Pseudaulacaspis pentagona (Targioni-Tozzetti) (Hemiptera: Diaspidae) which has a wide host range, is an important pest causing losses in yield. The insecticides are used for control against this pest but insecticidal control is difficult as scales protect themselves very effectively with hard, waxy armor. Also, the negative effects of the chemicals used in the control against benefical insects and with the increasing awareness on environmental issues, alternative methods were sought. Therefore, this study was performed to develop an alternative and effective control method for this pest by using biocontrol bacteria Bacillus pumilus (TV-67C), Brevibacillus brevis (CP-1) and Bacillus megaterium (TV-91C) under
\end{abstract}

*This study was submitted as an oral presentation at the "International Congress on Engineering and Life Science (ICELIS), 26-29 April 2018, Kastamonu, TURKEY" and published as an abstract in the abstract book 
controlled conditions. The death adult number of the pest was recorded and mortality rate was calculated. All of the tested bacterial strains showed mortality rates from $41.68 \%$ to 89.04\% against the white peach scale under controlled conditions. Consequently, our results indicated that especially B. pumilus strain TV-67C and B. brevis strain CP-1 can be used as biocontrol agents of $P$. pentagona.

Keywords: Pseudaulacaspis pentagona, White peach scale, Microbial control, Bacteria

\section{Introduction}

Pseudaulacaspis pentagona (Targioni-Tozzetti) (Hemiptera: Diaspidae) (the white peach scale) is one of the most damaging armoured scales. This pest is believed to have originated in China or Japan, although it was first reported in Italy in 1886 by Targioni (Brancsome, 2016). It is distributed throughout the World. P. pentagona threatened the silk industry in Italy because of killing mulberry trees and damaged the peach industry (Gossard, 1902; Van Duyn \& Murphey, 1971) in the United States in the early 1900s (Gossard, 1902), too (Hanks \& Denno, 1993). P. pentagona destroyed numerous peach orchards in Florida and south Georgia in the early part of this century (Brancsome, 2016). It is polyphagous species that infests mulberry, beside of various kinds of deciduous fruit trees, ornamental and wild plants (Ben-Doy et al., 2015). P. pentagona attacks twigs and branches of peach trees. It absorbs the sap and causes the leaves to deteriorate and the branches (Moussa et al., 2010).

The control of white peach scale is very hard because they cover themselves very effectively by their hard, waxy armor. Traditional control methods include insecticides as well as several pesticides. In general, control methods are applied to nymphs which is the most vulnerable periods of the pests (Brancsome, 2016), since adults are less affected from pesticide application due to their hard outer skeleton.

There are lots of studies in the world where natural enemies are used as biological control for this pest. Encarsia berlesei, Chifocorus bipusrufatus and Cybocephalus fodori minor are some important natural enemies and they have been effectively used in the control against this pest (Erkılıç \& Uygun, 1995; Follett et al., 2015). However, efficiency of natural enemies is reduced in last few years since producers used broad spectrum insecticides which have negative effects on natural enemies and environment. The increasing adverse effects of pesticides on the environment and humans reveal that biological control has high importance (Carruthers \& Hural, 1990; Inglis et al., 2001). That's why, for the management of pests it is desired to develop long-lasting and effective biological control methods that are not harmful to the environment. The use of microbial agents is one of the methods for this pest control. Many entomopathogens such as Bacillus can be mass produced, formulated, and applied to pest populations in a manner analogous to chemical pesticides, i.e. as nonpersistent remedial treatments that are released inundatively (Bhattarai et al., 2016).

The present study was planned and conducted with the aim to determine the insecticidal effect of a totally three bacterial strains against $P$. pentagona which lead to economical losses on controlled conditions. According to the carried literature search, this research is the first research in literature where bacteria are used in the microbial control of $P$. pentagona. 


\section{$\triangle 1$ Macrothink}

Journal of Agricultural Studies

ISSN 2166-0379

2020, Vol. 8, No. 4

\section{Material and Methods}

\subsection{Host Plant, Harmful Insect and Bacterial Strains}

Naturally infested (included P. pentagona) mulberry twigs (Morus alba) observed in Erzurum, Turkey (Figure 1a). Mulberry and P. pentagona were used as host plant and harmful insect in this study, respectively (Figure 1b).

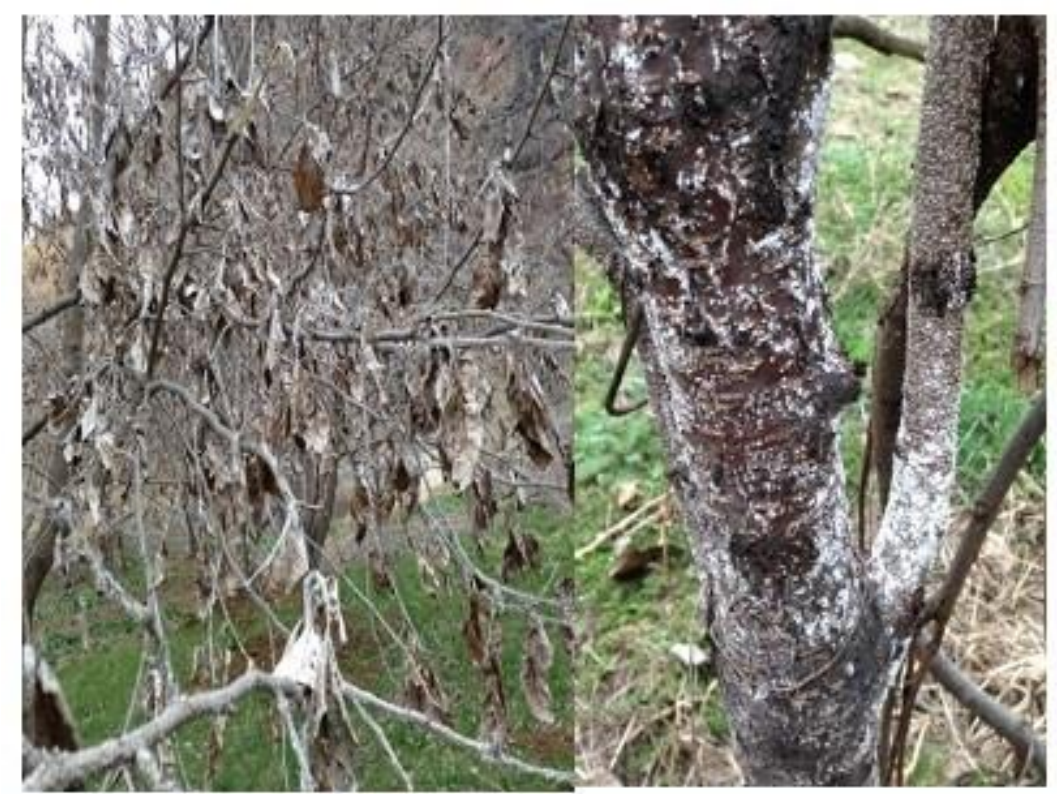

a
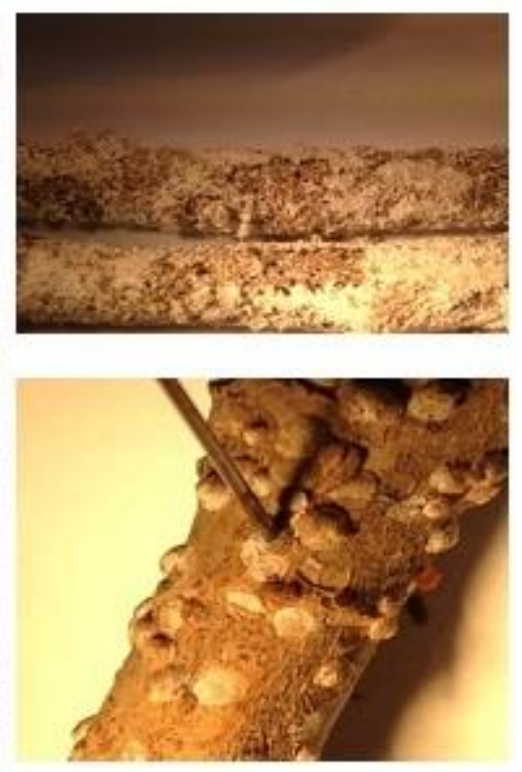

b

Figure 1. Land view of trees damaged with Pseudaulacaspis pentagona (a), naturally infested mulberry twigs with Pseudaulacaspis pentagona (b)

Bacterial strains CP-1, TV-67C and TV-91C were isolated from Ricania simulans, Rubus idaeus and Graminea sp., respectively in previous studies (Table 1) (Göktürk et al., 2018; Erman et al., 2010) and defined in the MIS based on fatty acid methyl esters. Stock cultures of the bacterial strains were kept in Atatürk University Faculty of Agriculture Plant Clinical Laboratory (AUFAPCL).

Table 1. Identification and similarity indexes (SIM) and hypersensitivity (HR) of biocontrol bacterial strains used in the study

\begin{tabular}{lllllc}
\hline Strain No & Isolated from & \multicolumn{1}{c}{$\begin{array}{c}\text { MIS } \\
\text { Identification results }\end{array}$} & SIM & HR & References \\
\hline CP-1 & Ricania simulans & Brevibacillus brevis & 0.650 & - & Erman et al., 2010 \\
TV-67C & Rubus idaeus & Bacillus pumilus & 0.630 & - & Göktürk et al., 2018 \\
TV-91C & Graminea sp. & Bacillus megaterium & 0.474 & - & Göktürk et al., 2018 \\
\hline
\end{tabular}

SIM: Similarity, -: Negative effect; HR: Hypersensitivity 


\subsection{Preparation of Bacterial Suspensions}

The bacterial suspensions were prepared according to Tozlu et al. (2019) and the bacteria density was adjusted at $\left(1 \times 10^{8} \mathrm{CFU} / \mathrm{ml}\right)$ by a spectrophotometry, sing nutrient broth medium (NB) and transferred to sterile spray bottles.

\subsection{Determination of the Bacterial Strains Insecticidal Effect Under Controlled Conditions}

The effectiveness of the bacterial strains against $P$. pentagona was tested using the mulberry twigs under controlled condition. Naturally infested with $P$. pentagona the mulberry twigs were brought to AUFAPCL. Twigs were divided into groups each included average of 20 adults of $P$. pentagona and placed in polyethylene lined plastic boxes $(19 \times 12.5 \times 7 \mathrm{~cm})$. About 180 adults of $P$. pentagona were sprayed by the three of bacterial suspensions $\left(10^{8} \mathrm{cfu} / \mathrm{ml}\right)(60$ adults/each bacterial suspention) and 60 adults of $P$. pentagona were sprayed by NB for control treatment. All plastic boxes were incubated at $25 \pm 2{ }^{\circ} \mathrm{C}$, in $65-70 \% \mathrm{RH}$ and under a photoperiod regime of 16:8 (light: darkness). The final evaluation of the trial was carried out and the mortality rates were determined during 18 days. The number of dead insects and mortality rates $(\%)$ of $P$. pentagona were recorded once every six days. Mortality rate was calculated with the following formula;

\section{Mortality rate $(\%)=\underline{100 \times \text { the number of dead adults in treatment }}$}

Total adult in treatment

Re-isolation from the adult insects that were determined to be infected according to the Koch Postulates was performed and the entomopathogenic bacterial strains were recovered. Experiment was carried out in 4 repetitions for each combination.

\subsection{Analysis of Results}

The data of study were analyzed using the JMP 5.0 program and apllications differences were determined according to ANOVA results and "LSMeans Differences Student's" multiple comparison test.

\section{Results}

The effects of $B$. brevis, B. pumilus and B. megaterium strains on $P$. pentagona adults were tested. The results showed that all the bacteria have insecticidal activity in controlled coditions. The adults started to die in all applications except the control on the sixth day (Figure 2). The dead adult number according to days during the 18 days follow-up period are given in Figure 2. The percentages of dead adults were $74.94 \%$ (TV-67C), 72.27\% (CP-1) and 27.29 (TV-91C) during 6 days, 92.17\% (TV-67C), 82.17\% (CP-1) and 42.5\% (TV-91C) during 12 days and 100\% (TV-67C), 95.24\% (CP-1) and 55.25\% (TV-91C) during 18 days (Figure 2). 


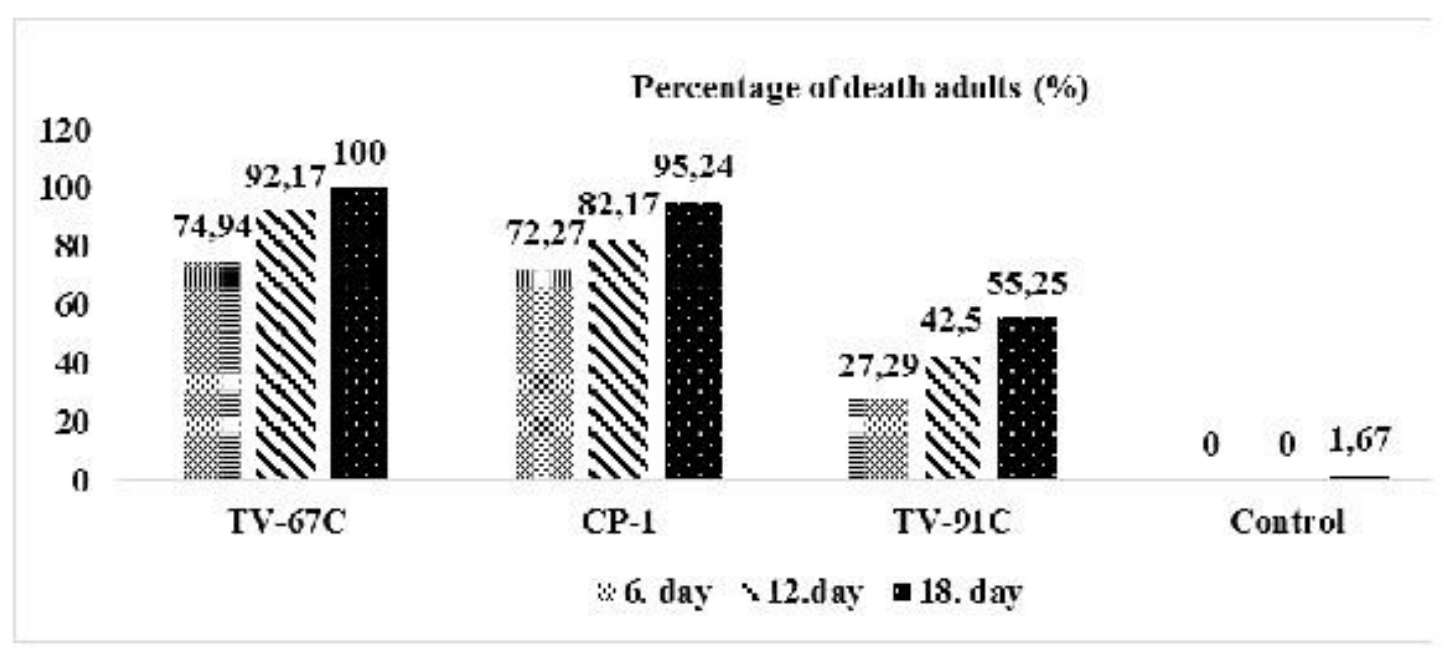

Figure 2. Pseudaulacaspis pentagona dead adults number according to days during the 18 days follow-up period

The insecticidal activities of bacterial strains tested against $P$. pentagona adults on mulberry twigs are given in Table 2. According to adults percentage mortality, the difference between applications was found to be statistically significant (F: 123.1; $<<0.01)$. Among the tested three bacteria, B. pumilus and B. brevis were the most effective strains causing $89.04 \%$ and $83.23 \%$ (insignificantly different) mortality rate in the adult of $P$. pentagona, respectively. $B$. megaterium strain showed $41.68 \%$ (which was significantly different from the other two bacteria) mortality rate (Table 2 ).

Table 2. The insecticidal effect of three different bacterial suspensions against adults of Pseudaulacaspis pentagona under controlled condition

\begin{tabular}{|c|c|}
\hline Applications & Mean death adult ratio $(\%) \pm \mathrm{SD}$ \\
\hline TV-67C (B. pumilus) & $89.04 \pm 12.82 \quad \mathrm{~A}$ \\
\hline CP-1 (B. brevis) & $83.23 \pm 11.52 \quad \mathrm{~A}$ \\
\hline TV-91C (B. megaterium) & $41.68 \pm 13.998 \quad \mathrm{~B}$ \\
\hline Control & $0.56 \pm 0.96 \mathrm{C}$ \\
\hline $\mathbf{C V}$ & 13.90 \\
\hline LSD & 7.21 \\
\hline
\end{tabular}

Mean values Mean \pm Standard deviation: in the same column by the same letter are not significantly different to the test of LS Means Differences Student's $(p<0.01)$ 


\section{MInstitute ${ }_{\text {Mnk }}^{\text {Macrothink }}$}

Journal of Agricultural Studies

ISSN 2166-0379

2020, Vol. 8, No. 4

The effects of the most effective bacterial strains B. pumilus TV-67C strain and control treatment against $P$. pentagona adults were given in Figure 3. TV-67C bacterial strain melted the $P$. pentagona adults armour within 6 days.
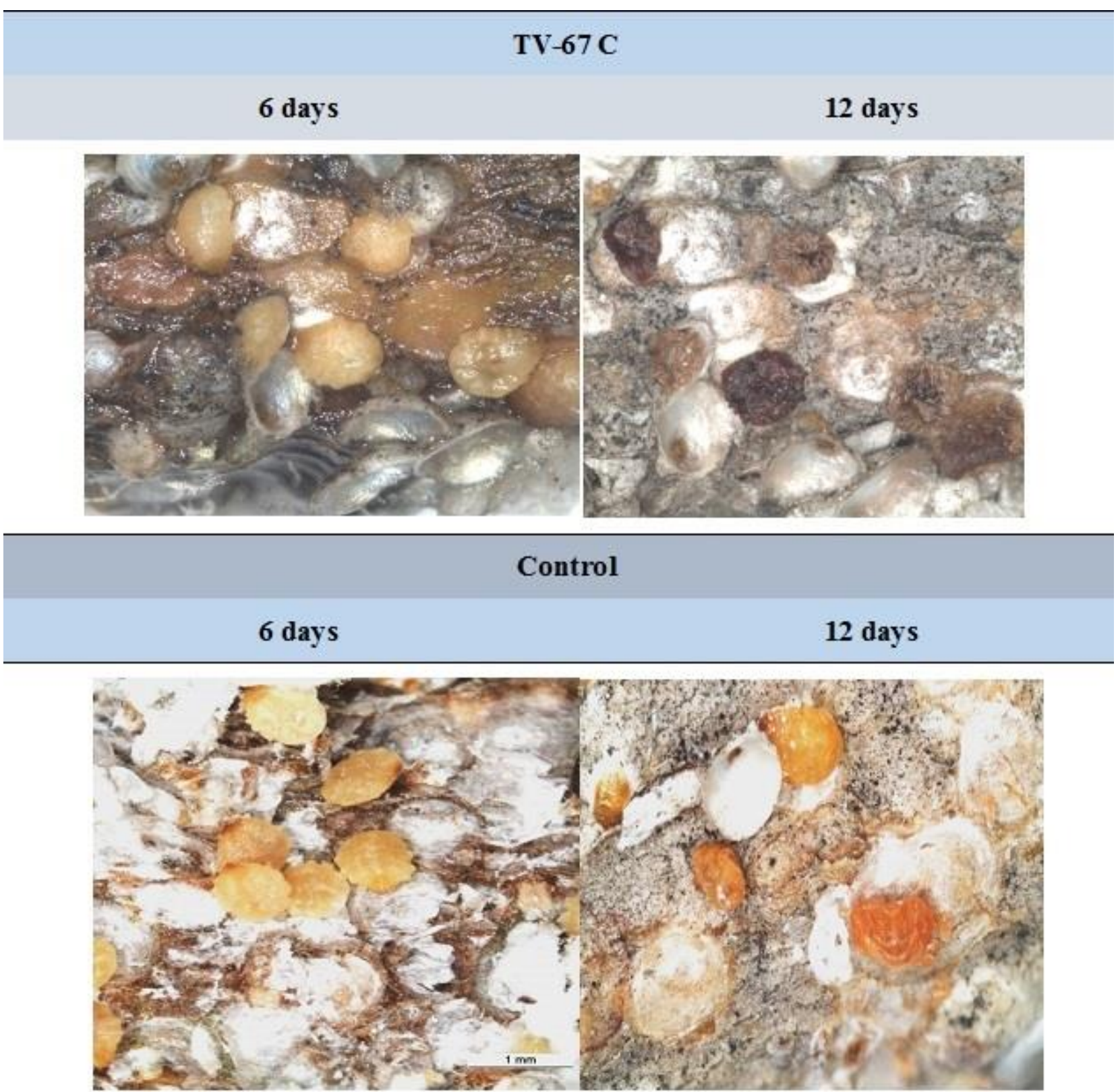

Figure 3. The most effective bacterial strains TV-67C (Bacillus pumilus) and control treatment

\section{Discussion}

Entomopathogens are one of the most effective factors regulating pest populations. Throughout the world, many biopesticides are widely used in greenhouse products, ornamental plants, stored products, forest products, vegetable and fruit garden products as biological control of pests (Lacey et al., 2001). Bacillus species are the most important 
species for microbial control. It is known that Bacillus species particularly Bacillus thuringiensis, B. brevis, B. cereus, B. circulans, B. megaterium and B. subtilis are used for biotechnological and industrial applications (Xu \& Côté, 2003; Rooney et al., 2009). B. pumilus which has a high effect against $P$. pentagona in this study is found everywhere. It is stated in previoulsly studies that some of the B. pumilus isolates result fungicidal activity (Bottone \& Peluso, 2000; Lehman et al., 2001), some result strong antibacterial activity (Aunpad \& Na-Bangchang, 2007), some promotes plant growth, (Raunpach \& Kloepper, 1998; Yan et al., 2002; Joo et al., 2005; Forchetti et al., 2007), also some others are used as probiotics (Green et al., 1999; Caldini et al., 2002; Duc Le et al., 2004). B. pumilus was first identified by Heins as insect pathogen against Diabrotica undecimpunctata and Spodoptera exigua. In one study was reported that B. pumilus was highly toxic to the larvae of Ceratitis capitata. It was also pointed out that it is important to develop biotechnological study strategies to reduce economic losses caused by $C$. capitata (Molina et al., 2010). Rishad et al. (2017) reported that $B$. pumilus exhibited high chitinase activity and the enzyme also exhibited biopestisidal role against larvae of Scirpophaga incertulas, a serious agricultural pest of rice, too. Another bacterial species B. brevis produced different antibiotics such as gramicidin S (Edwads \& Seddon, 2001), toadadine (Song et al., 2012), ethylparaben (Che et al., 2015) and enzyme such as chitinase (Ahmad \& Omar, 2014; Minghui et al., 2015). Therefore, it has antimicrobial effects against soil-borne pathogens such as Fusarium (Ahmad \& Omar, 2014) and and insecticidal effects against pests such as Bruchus dentipes (Tozlu et al., 2011; Blibech et al., 2012), Spodoptera littoralis (Sakr, 2017) and Halyomorpha halys (Tozlu et al., 2019).

B. megaterium, which is $41.68 \%$ effective in this study, is the centre of many studies showing that it is a potential biocontrol agent against plant diseases (Tozlu et al., 2019; Trivedi \& Pandey, 2008; Matar et al., 2009; Velmurugan et al., 2009). In addition, B. megaterium tested against insecticidal activity against Agrotis segetum larvae was found to be effective in $30 \%$ in another study (Sevim et al., 2010). This species is obtained from the stomach of the pest Limonius canus LeConte (Coleoptera: Elateridae) an important potato pest (Lacey et al., 2007). Furthermore, this species can produce amylase hydrolytic enzyme responsible for carbohydrate digestion and this makes species to have more importance (Parasanna et al., 2014).

As far as we know, this is the first study related to the microbial control of $P$. pentagona. 3 bacterial isolates were tested against $P$. pentagona under controlled conditions and all of the bacterial isolates tested effected in varying percentages.

\section{Conclusion}

It needs to be considered that use of intensive chemicals for combating this pest results adverse effects on natural enemies, predators and parasitoids, of this pest. That's why, it is very important to include effective and resistant biopesticides which has no toxic effects on neither environment nor human health in control system against $P$. pentagona in places where natural enemies are absent or less active. This study emphasizes that a risk-free microbial agents can be successfully applied to $P$. pentagona instead of chemical pesticides in integrated pest management studies. 


\section{References}

Ahmad, A. I. S., \& Omar, A. M. (2014). Antagonistic and inhibitory effect of some plant rhizo-bacteria against different Fusarium isolates on Salvia officinalis. American-Eurasian Journal of Agricultural and Environmental Sciences, 14(12), 1437-1446. https://doi.org/10.5829/idosi.aejaes.2014.14.12.12488

Aunpad, R., \& Na-Bangchang, K. (2007). Pumilicin 4, a novel bacteriocin with anti-MRSA and anti-VRE activity produced by newly isolated bacteria Bacillus pumilus strain WAPB4. Current Microbiology, 55, 308. http://doi.org/10.1007/s00284-006-0632-2

Ben-Dov, Y., Miller, D. R., \& Gibson, G. A. P. (2015). ScaleNet Query Results, Available at: http://www.sel.barc.usda.gov/scalenet/scalenet.htm (July, 1, 2020)

Bhattarai, S. S., Bishwokarma, S. K., Gurung, S., Dhami, P., \& Bishwokarma, Y. (2016). Efficacy of entomopathogens for control of blue pumpkin beetle (Aulacophora nigripennis Motschulsky, 1857) in sponge gourd (Luffa cylindrica) under laboratory condition at Paklihawa, Nepal. Global Journal of Biology, Agriculture and Health Sciences, 5(2), 102-105. http://gifre.org (July, 1, 2020)

Blibech, I., Ksantini, M., Chajeb, I., Jlassi, B., \& Rhouma, A., Jaoua, S., \& Aifa, S. (2012). Isolation of entomopathogenic Bacillus from a biodynamic olive farm and their pathogeneicity to Lepidopteran and Coleopteran insect pests. Crop Protection, 31(1), 72-77. https://doi.org/10.1016/j.cropro.2011.09.020

Bottone, E. J., \& Peluso, R. (2000). Bacillus pumilus strain. U.S. patent 6,090,613, 18 July 2000

Branscome, D. (2016). White Peach Scale, Pseudaulacaspis pentagona (Targioni) (Insecta: Hemiptera: Diaspididae) https://edis.ifas.ufl.edu/pdffiles/IN/IN23300.pdf (July, 1, 2020)

Caldini, G., Trotta, F., \& Cenci, G. (2002). Inhibition of 4-nitroquinoline-1-oxide genotoxicity by Bacillus strains. Research in Microbiology, 153, 165-171. https://doi.org/10.1016/S0923-2508(02)01302-5

Carruthers, R. I., \& Hural, K. (1990). Fungi as naturally ocurring entomopathogens. Symposia on Molecular and Cellular Biology, 112, 115-138. https://www.cabdirect.org/cabdirect/abstract/19910505407 (July, 1, 2020)

Che, J., Liu, B., Ruan, C., Tang, J., \& Huang, D. (2015). Biocontrol of Lasiodiplodia theobromae, which causes black spot disease of harvested wax apple fruit, using a starin of Brevibacillus brevis FJAT-08009-GLX. Crop Protection, 67, 178-183. http://doi.org/10.1016/j.cropro.2014.10.012

Duc Le, H., Hong, H. A., Barbosa, T. M., Henriques, A. O., \& Cutting, S. M. (2004). Characterization of Bacillus probiotics available for human use. Applied Environmental Microbiology, 70, 2161-2171. http://doi.org/10.1128/AEM.70.4.2161-2171.2004

Edwads, S. G., \& Seddon, B. (2001). Mode of antagonism of Brevibacillus brevis against Botrytis cinerea in vitro. Journal of Applied Microbiology, 91(4), 652-659. http://doi.org/10.1046/j.1365-2672.2001.01430.x 
Erkılıç, L., \& Uygun, N. (1995). Distribution, population fluctuations and natural enemies of white peach scale, Pseudaulacaspis pentagona (Targioni-Tozzetti) (Hom.: Diaspididae) in the east Mediterranean region of Turkey. Israel Journal of Entomology 29, 191-198. http://doi.org/10.5281/zenodo.819733

Erman, M., Kotan, R., Çakmakcı, R., Çı̆̆, F., Karagöz, K., \& Sezen, M. (2010). Effect of nitrogen fixing and phosphate-solubilizing Rhizobacteria isolated from Van Lake Basin on the growth and quality properties in wheat and sugar beet. Turkey IV. Organic Farming Symposium, 28 June-1 July, Erzurum, Turkey, 325-329

Follett, P., Neumann, G., Hollingsworth, R., Swedman, A., \& Sibuca, R. (2015). Release and establishment of Encarsia diaspidicola (Hymenoptera: Aphelididae) against white peach scale (Hemiptera: Diaspididae) in papaya. Proceedings of the Hawaiian Entomological Society, 47, 51-54. http://hdl.handle.net/10125/38672 (July, 1, 2020)

Forchetti, G., Masciarelli, O., Alemano, S., Alvarez, D., \& Abdala, G. (2007). Endophytic bacteria in sunflower (Helianthus annuus L.): isolation, characterization, and production of jasmonates and abscisic acid in culture medium. Applied Microbiology and Biotechnology, 76, 1145-1152. http://doi.org/10.1007/s00253-007-1077-7

Göktürk, T. Tozlu, E., \& Kotan, R. (2018). Prospects of entomopathogenic bacteria and fungi for biological control of Ricania simulans (Walker 1851) (Hemiptera: Ricaniidae). Pakistan Journal of Zoology, 50(1), 75-82. http://doi.org/10.17582/journal.pjz/2018.50.1.75.82

Gossard, H. A. (1902). Two peach scales. Florida Agricultural Experimental Station Bulletin $61,492-498$

Green, D. H., Wakeley, P. R., Page, A., Barnes, A., Baccigalupi, L., Ricca, E., \& Cutting, S. (1999). Characterization of two Bacillus probiotics. Applied Environmental Microbiology, 65, 4288-4291. http://doi.org/10.1128/AEM.65.9.4288-4291.1999

Hanks, L. M., \& Denno, R. F. (1993). The white peach scale, Pseudaulacaspis pentagona (Targioni-Tozzetti) (Homoptera: Diaspididae): Life history in Maryland, host plants, and natural enemies. Proceeding of the Entomological Society of Washington, 95 (1), 79-98. http://www.life.illinois.edu/hanks/pdfs/Hanks\%20and\%20Denno\%201993\%20b.pdf (July, 1, 2020)

Inglis, G. D., Goettel, M.S., Butt, T. M., \& Strasser, H. (2001). Use of hyphomycetous fungi for managing insect pests. In: T.M. Butt, C. Jackson \& N. Magan (Eds.), Fungi as biocontrol agents: progress problems and potential, CABI Publishing, 23-69. https://www.cabi.org/isc/fulltextpdf/2001/20013125209.pdf (July, 1, 2020)

Joo, G. J., Kim, Y. M., Kim, J. T., Rhee, I. K., Kim, J. H., \& Lee, I. J. (2005). Gibberellins-producing rhizobacteria increase endogenous gibberellins content and promote growth of red peppers. The Journal of Microbiology, 43, 510-515. https://pubmed.ncbi.nlm.nih.gov/16410767/ (July, 1, 2020)

Lacey, L. A., Frutos, R., Kaya, H. K., \& Vail, P. (2001). Insect pathogens as biological control agents: do they have a future? Biological Control, 21, 230-248. 
https://doi.org/10.1006/bcon.2001.0938

Lacey, L. A., Unruh, R. T., Simkins, H., \& Thomsen-Archer, K. (2007). Gut bacteria associated with the pacific coast wireworm, Limonius canus, inferred from 16s rDNA sequences and their implications for control. Phytoparasitica, 35, 479-489. http://doi.org/10.1007/BF03020607

Lehman, L. J., Mccoy, R. J., Messenger, B. J., Manker, D. C., Orjala, J. E., Lindhard, D. \& Marrone, P. G. (2001). Strain of Bacillus pumilus for controlling plant diseases caused by fungi. U.S. patent $6,245,551$

Matar, S. M., El-Kazzaz, S. A., Wagih, E. E., El-Diwany, A. I., Moustafa, H. E., Abo-Zaid, G. A., \& Hafez, E. E. (2009). Antagonistic and inhibitory effect of Bacillus subtilis against certain plant pathogenic fungi. Biotechnology, 8(1), 53-61. http://doi.org/10.3923/biotech.2009.53.61

Minghui, S. U., Xueqin, H. U., Donghua, G. U., Hongbin, Z., \& Xiaolong, C. (2015). Purification and characterization of chitinase from the fermentation broth of Brevibacillus brevis FM4B. Food Science, 36(19), 176-179

Molina, C. A., Cana-Roca, J. F., Osuna, A., \& Vilchez, S. (2010). Selection of a Bacillus pumilus strain highly active against Ceratitis capitata (Wiedemann) larvae. Applied and Environmental Microbiology, 76(5), 1320-1327. http://doi.org/10.1128/AEM.01624-09

Moussa, S. F. M., Ramdan, R. H., \& Attia, S. A. (2010). Seasonal fluctuation of the white peach scale insect, Pseudulacaspis pentagona (Targioni) and its associated parasitoid, Aphytis sp. At Mett-Ghamer, Dakahlyia Governorate, Egypt. Egyptian Academic Journal of Biological Sciences, 3(1), 1-9. http://doi.org/10.21608/eajbsa.2010.15203

Prasanna, P. H. P. Grandison, A. S., \& Charalampopoulos, D. (2014). Bifidobacteria in milk products: An overview of physiological and biochemical properties, exopolysaccharide production, selection criteria of milk products and health benefits. Food Research International, 55, 247-262. https://doi.org/10.1016/j.foodres.2013.11.013

Raupach, G. S., \& Kloepper, J. W. (1998). Mixtures of plant growth- promoting rhizobacteria enhance biological control of multiple cucumber pathogens. Phytopathology, 88, 1158-1164. http://doi.org/10.1094/PHYTO.1998.88.11.1158

Rishad, K. S., Rebello, S., Shabanamol, P. S., \& Jisha, M. S. (2017). Biocontrol potential of Halotolerant bacterial chitinase from high yielding novel Bacillus pumilus MCB-7 autochthonous to mangrove ecosystem. Pesticide Biochemistry and Physiology, 137, 36-41. https://doi.org/10.1016/j.pestbp.2016.09.005

Rooney, A. P., Price, N. P. J., Ehrhardt, C., Swezey, J. L., \& Bannan, J. D. (2009). Phylogeny and molecular taxonomy of the Bacillus subtilis species complex and description of Bacillus subtilis subsp. inaquosorum subsp. nov. International Journal of Systematic and Evolutionary Microbiology, 59, 2429-2436. http://doi.org/10.1099/ijs.0.009126-0

Sakr, H. H. (2017). Insecticidal activity of Brevibacillus brevis (Paenibacillaceae) bacterial culture filtrate on Spodoptera littoralis (Lepidoptera: Noctuidae) larvae. The Egyptian 
Journal of Experimental Biology (Zoology), 13(2), 331-342. http://doi.org/10.5455/egysebz.20170925110624

Sevim, A., Demirbağ, Z., \& Demir, I. (2010). A new study on the bacteria of Agrotis segetum Schiff. (Lepidoptera: Noctuidae) and their insecticidal activities. Turkish Journal of Agriculture and Forestry, 34, 333-342. http://doi.org/10.3906/tar-0902-9

Song, Z., Liu, Q., Guo, H., Ju, R., Zhao, Y., Li, X. \& Liu, X. (2012). Tostadin, a novel antibacterial peptide from an antagonistic microorganism Brevibacillus brevis XDH. Bioresource Technology, 111, 504-506. https://doi.org/10.1016/j.biortech.2012.02.051

Tozlu, E., Dadaşoğlu, F., Kotan, R., \& Tozlu, G. (2011). Insecticidal effect of some bacteria on Bruchus dentipes Baudi (Coleoptera: Bruchidae). Fresenius Environmental Bulletin, 20, 918-923

Tozlu, E., Saruhan, I., Tozlu, G., Kotan, R., Dadaşoğlu, F., \& Tekiner, N. (2019). Potentials of some entomopathogens against the brown marmorated stink bug, Halyomorpha halys (Stål, 1855) (Hemiptera: Pentatomidae). Egyptian Journal of Biological Pest Control, 29, 76. https://doi.org/10.1186/s41938-019-0176-y

Trivedi, P., \& Pandey, A. (2008). Plant growth promotion abilities and formulation of Bacillus megaterium strain B 388 (MTCC 6521) isolated from a temperate Himalayan location. Indian Journal of Microbiology, 48(3), 342-347. http://doi.org/10.1007/s12088-008-0042-1

Van Duyn, J. W., \& Murphey, M. (1971). Life history and control of white peach scale. Pseudaulacaspis pentagona (Homoptera: Coccoidea). Florida Entomologist, 54, 91-95. http://doi.org/10.2307/3493794

Velmurugan, N., Choi, M. S., Han, S. S., \& Lee, Y. (2009). Evaluation of antagonistic activity of Bacillus subtilis and Bacillus licheniformis against wood staining fungi: in vitro and in vivo experiments. The Journal of Microbiology, 47(4), 385-392. http://doi.org/10.1007/s12275-009-0018-9

Xu, D., \& Côté, J. C. (2003). Phylogenetic relationships between Bacillus species and related genera inferred from comparison of 3' end 16S rDNA and 5' end 16S-23S its nucleotide sequences. International Journal of Systematic and Evolutionary Microbiology, 53, 695-704. http://doi.org/10.1099/ijs.0.02346-0

Yan, Z., Reddy, M. S., Ryu, C. M., Mcinroy, J. A., Wilson, M., \& Kloepper, J. (2002). Induced systemic protection against tomato late blight elicited by plant growth-promoting rhizobacteria. Phytopathology,

92 , 1329-1333. http://doi.org/10.1094/PHYTO.2002.92.12.1329

\section{Copyright Disclaimer}

Copyright for this article is retained by the author(s), with first publication rights granted to the journal.

This is an open-access article distributed under the terms and conditions of the Creative Commons Attribution license (http://creativecommons.org/licenses/by/4.0/). 